\section{En folkefiende i San Francisco}

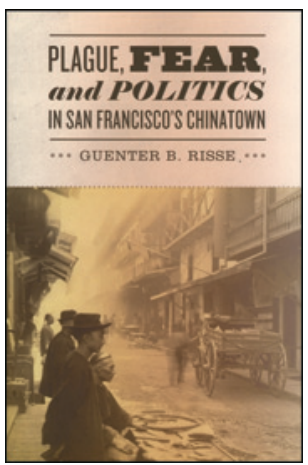

Guenter B. Risse

Plague, fear and politics

in San Francisco's Chinatown

371 s, ill. Baltimore, MD: The Johns Hopkins

University Press, 2012. Pris USD 40

ISBN 978-1-4214-0510-0

Pest, mest kjent som svartedauden på midten av 1300-tallet, har forekommet både før og senere. Den bakteriologiske årsaken ble påvist på slutten av 1800-tallet da Yersinia pestis ble beskrevet. Moderne bakteriologiske metoder for diagnostikk av pest ble utviklet i forbindelse med en epidemi i Det fjerne østen. USAs vestkyst hadde allerede da nære forbindelser med Kina både i form av import av matvarer og arbeidskraft. Tidlig i 1900 ble det påvist ett tilfelle av pest i San Franciscos Chinatown, noe som startet den historien Risse gjør rede for.

Forfatteren, som er professor i medisinsk historie ved University of California, San Francisco, angir i forordet at han har vært opptatt av pestepidemien i San Francisco i en årrekke, og at han som emeritus satte seg som mål å gi en utførlig redegjørelse for epidemien. Hans hovedbudskap er at pestfrykten førte til stigmatisering og diskriminering av den kinesiske minoriteten i San Francisco som ble utsatt for urimelige inngrep fra helsemyndighetene, bl.a. i form av karantene og sanering av helsefarlige forhold i Chinatown. Dette budskapet er til dels sterkt moraliserende, og leseren blir, gitt den aktuelle konteksten, ikke uten videre overbevist om dets berettigelse. Tvert imot beskriver forfatteren en annen problemstilling som synes å være langt mer relevant: konflikten mellom helsemyndighetene på den ene siden og det lokale næringslivet sammen med lokale politikere, fortrinnsvis republikanere, på den annen side.

Helsearbeiderne kjempet en omfattende kamp for å overbevise motparten om at det forelå pest i San Francisco i 1900. De ble beskyldt for å forfalske sine bakteriologiske funn. En føderal gransking bekreftet funnene, men konklusjonen ble ikke tillatt offentliggjort. Nødvendige forebyggende tiltak som karantene og sanering av helsefarlige forhold ble effektivt motarbeidet av en uventet allianse mellom kinesere, næringsliv og republikanere, til tross for høyst ulike mål og på tvers av fremmedfrykt og stigmatisering.

Begrunnelsen var faren for at oppmerksomheten rundt pestepidemien og de forebyggende tiltakene skulle få ødeleggende konsekvenser for næringslivet. Lederen av kampen mot pesten i San Francisco ble erklært «persona non grata» og måtte forlate byen. Tankene går til En Folkefiende.

De samfunnsmessige konsekvensene av pestepidemien var etter hvert ganske omfattende i form av forebyggende tiltak, men omfanget av epidemien, som varte i ca. 5 år, var relativt begrenset, med 119 tilfeller offisielt bekreftet. Epidemien representerte sannsynligvis en enorm trussel mot samfunnet, men ble bekjempet med midler som samfunnet ikke uten videre aksepterte.

Historien om pesten illustrerer på denne måten et viktig paradoks i forebyggende medisin. Nettopp dette forklarer og gjør boken interessant. 18. april 1906 skjedde det imidlertid enorm katastrofe som ikke bare satte pesten og debatten rundt den i skyggen, men nesten raderte den ut av historien, nemlig jordskjelvet.

Boken er spennende lesning og anbefales alle som er interessert i mikrobiologi, samfunnsmedisin og medisinsk historie.

\section{Studenter, se her!}

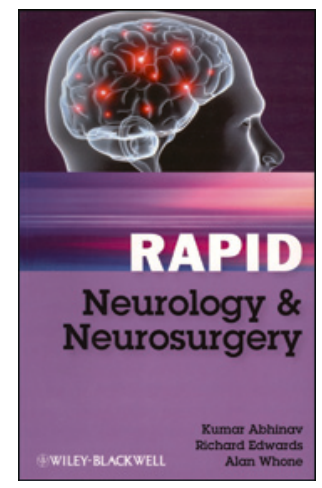

Kumar Abhinav, Richard Edwards, Alan Whone

Rapid neurology and neurosurgery 188 s, tab, ill. Chichester: Wiley-Blackwell, 2012. Pris GBP 20 ISBN 978-0-470-65443-9

I denne lille og kondenserte boken, som tydeligvis er én av flere i en serie med «Rapids», har forfatterne som erklært mål å hjelpe studenter til en «focused exam preparation». I tillegg lover de at dette skal skje raskt («rapid»). Ettersom målsettingen for medisinstudiet (og for all annen læring for den del) bør være å lære for livet, ikke for eksamen, var jeg i utgangspunktet svært skeptisk da jeg fikk den til anmeldelse, fordi jeg trodde «rapid» måtte være synonymt med «overfladisk». Det hadde jeg ingen grunn til.

Det er utrolig hvor mye fakta de tre forfatterne fra Bristol, to nevrokirurger og én nevrolog, har fått plass til. Overflødige ord er skrellet vekk, skriften er liten, og det er også linjeavstanden. Stoffet er i tillegg ytterligere kondensert i flere oversiktlige tabeller. Illustrasjonene er mange nok - og gode. Det gjelder så vel radiologiske bilder som strektegninger.

Det sier seg selv at noen emner kan falle ut eller bli overfladisk behandlet med en så stram redigering, men stort sett holder boken mål - og vel så det. Jeg har bare funnet ett utsagn som jeg er uenig i så langt: Forfatterne anbefaler operasjon innen 48 timer, «preferably within 24 hours if possible», ved cauda equina-syndrom med blære- og rektumparese - det er altfor lang tid!

Denne boken holder ikke som eneste forberedelse til eksamen den krever at studenten kan noe om emnet fra før for å kunne dra full nytte av innholdet. Dersom den kombineres med en større lærebok er den imidlertid, som forfatterne skriver, velegnet til fokusert eksamensforberedelse.

Ikke bare studenter, som leser til eksamen, vil ha nytte av denne utgivelsen. Også helt ferske (førsteårs) utdanningskandidater i disse fagene tror jeg kan ha glede av den - i frakkelommen - for en kjapp sjekk og oppdatering hver gang man støter på en ny tilstand.

Det er mulig at lesere med hang til det nevrologiske bør ta denne anmeldelsen med en klype salt, anmelderens begrensede nevrologiske kompetanse tatt i betraktning. Det umiddelbare inntrykket er likevel at nevrologikapitlene er like gode som de nevrokirurgiske.

En liten pussighet til slutt: De tre forfatterne, som ikke på noen måte synes å være i slekt, og som alle har skrevet under forordet, begynner dette slik: «My late grandfather, a university professor, used to ...»

\section{Knut Wester}

Institutt for kirurgiske fag

Universitetet i Bergen 